\title{
Conjunctival Limbal Autograft Implantation in Primary and Recurrent Pterygium
}

\author{
(D) Ali Demircan \\ Prof. Dr. N. Resat Belger Beyoglu Eye Training and Research Hospital, Istanbul, Turkey
}

\begin{abstract}
Objectives: The aim of this study was to evaluate the clinical results and recurrence rate after pterygium excision with a conjunctival limbal autograft in patients with primary and recurrent pterygium.

Methods: Patients who had primary (Group I) or recurrent (Group 2) pterygium and who underwent pterygium excision with a conjunctival limbal autograft implantation (with interrupted 10-0 nylon sutures or fibrin glue) were retrospectively reviewed. Only patients with a follow-up of at least 6 months were included. The primary outcome measures were the spherical equivalent (SE) of manifest refraction, uncorrected distance visual acuity, distance corrected visual acuity, topographical astigmatism, and keratometry values measured preoperatively and at 3- and 6-month follow-up visits. Complication and recurrence data were also recorded.

Results: A total of 145 patients were included in the study. There were no statistically significant differences between the groups preoperatively. When all of the cases were evaluated, there was a statistically significant correlation between pterygium length and corneal astigmatism. After surgery, SE, corneal astigmatism, and topographical astigmatism measurements had decreased significantly in both groups when compared with the preoperative values. Postoperative visual acuity, corneal astigmatism, and manifest cylinder values were similar between the groups. There was no recurrence in Group I. The recurrence rate was $1.75 \%$ in Group 2.

Conclusion: Pterygium excision with a conjunctival limbal autograft is a safe and effective method for the surgical treatment of primary and recurrent pterygium. The recurrence rate was very low.

Keywords: Autograft, fibrin glue, pterygium, suture.
\end{abstract}

\section{Introduction}

Pterygium is a common ocular surface disease originating in the conjunctiva and extending to the cornea; the incidence rate is between $0.7 \%$ and $31 \%(1-3)$. The standard treatment option for pterygium is surgical excision, but the recurrence rate after surgery has been quite high (24\%-89\%) (4). The average length of time after the surgery before recurrence has been reported as 3.13 months. Therefore, multiple strategies and new techniques have been developed to reduce the high rate of pterygium recurrence, including limbal conjunctival autograft, human amniotic membrane grafting, beta-irradiation, stem cell transplantation, and the use of mitomycin- $C$ and fibrin glue (FG) (5-I I).

Conjunctival or limbal conjunctival autograft is currently thought to be the best treatment, with a low recurrence rate ranging from $1.9 \%$ to $5.3 \%$, and a high degree of safety, according to some studies $(12-15)$. These treatments have also been demonstrated to be more effective at treating recurrent pterygium than other techniques (16). Although the most common method of conjunctival autograft fixation in pterygium surgery is the use of absorbable or non-ab-

Address for correspondence: Ali Demircan, MD. Prof. Dr. N. Resat Belger Beyoglu Eye Training and

Research Hospital, 34421 Istanbul, Turkey

Phone: +90 5068544299 E-mail: alidemircanctf@yahoo.com

Submitted Date: May 18, 2018 Accepted Date: May 29, 2018 Available Online Date: July 03, 2018

${ }^{\circ}$ Copyright 2018 by Beyoglu Eye Training and Research Hospital - Available online at www.beyoglueye.com 
sorbable sutures, FG is an alternative to sutures for conjunctival autograft fixation.

The aim of this study was to evaluate and compare the effectiveness of conjunctival autograft implantation using sutures and FG in primary and recurrent pterygium.

\section{Methods}

This study adhered to the tenets of the Helsinki Declaration, and it was approved by the institutional review board of Beyoglu Training and Research Hospital. Patients who had primary (Group I) or recurrent (Group 2) pterygium and who underwent pterygium excision with conjunctival autograft implantation between September 20II and July 2012 were included in the study. Only patients with a follow-up of at least 6 months were included. Patients with a history of trauma, use of a topical agent, or previous ocular surgery were not included in this study. The main outcome measures were spherical equivalent (SE) of manifest refraction, uncorrected distance visual acuity (UCVA), distance corrected visual acuity (DCVA), topographical astigmatism, and keratometry values preoperatively and at postoperative 3- and 6-month follow-up visits. The Sirius corneal topography system (Costruzioni Strumenti Oftalmici, Florence, Italy) was used for corneal topography examinations. Anterior segment photography was taken preoperatively and at each postoperative visit. The length of the pterygium tissue over the cornea was measured from the limbus in anterior segment images.

\section{Surgical Methods}

All of the procedures were performed by a single surgeon using subconjunctival anesthesia. The leading edge of the pterygium was avulsed from the cornea and the pterygium tissue over the corneal surface was dissected with a crescent knife. Remaining pterygium tissue over the bulbar conjunctiva was removed with scissors. The superotemporal bulbar conjunctiva was used to harvest a rectangular limbal conjunctival autograft to match the size of the bare sclera left after the pterygium excision. The conjunctival graft was sutured in place with 10-0 interrupted nylon sutures or FG (Tisseel; Baxter International, Inc., Deerfield, IL, USA). All of the patients received a topical antibiotic and a topical steroid 4 times a day for I month. Suture removal was performed 2 weeks postoperatively in patients with sutured conjunctival grafts.

\section{Statistical Methods}

IBM SPSS Statistics for Windows, (Version 22.0; IBM Corp., Armonk, NY, USA) was used to perform the statistical analysis. Mean and SD were used for descriptive statistics. The Shapiro-Wilks test was used to test the normality of data.
Intergroup comparisons were conducted using Student's ttest for parametric variables, and the Mann-Whitney $U$ for non-parametric data.

\section{Results}

In all, 145 patients were included in the study. The mean length of follow-up was 10.92 \pm 4 . I8 months for Group I and I I.20 \pm 4.25 months for Group 2. The preoperative characteristics of the patients are shown in Table I and Table 2. There were no statistically significant differences between the groups preoperatively. When all of the cases were evaluated, it was observed that there was a statistically significant correlation between pterygium length and corneal astigmatism (Pearson correlation analysis: $r=0.657 ; p<0.00 I$ ).

There was a statistically significant increase in UCVA and CDVA after the operation in both groups $(p<0.00$ I for UCVA and CDVA in GroupI and Group 2). SE, corneal astigmatism, and topographical astigmatism decreased significantly in both groups when compared with the preoperative values $(p<0.001$ for UCVA and CDVA in Groupl and Group 2). The postoperative visual acuity, corneal astigmatism, and manifest cylinder values were similar between the groups. The postoperative findings are presented in Table 3 and the postoperative complications are provided in Table 4.

Table I. Preoperative demographic data

\begin{tabular}{lccc} 
& $\begin{array}{c}\text { Group I } \\
(\mathbf{n}=\mathbf{8 8})\end{array}$ & $\begin{array}{c}\text { Group 2 } \\
(\mathbf{n}=\mathbf{5 7})\end{array}$ & $\mathbf{p}$ \\
\hline Fibrin glue & 43 & 26 & $\mathrm{n} / \mathrm{a}$ \\
Nylon suture & 45 & 31 & $\mathrm{n} / \mathrm{a}$ \\
Age (years) Mean \pm SD & $48.79 \pm 12.9$ & $50.94 \pm 11.5$ & 0.78 \\
Gender (male/female) & $55 / 33$ & $36 / 21$ & 0.82 \\
Pterygium length (mm) Mean $\pm S D$ & $3.46 \pm 0.9$ & $3.1 \pm 1.05$ & 0.69
\end{tabular}

n/a: not applicable.

Table 2. Preoperative clinical data of the groups

\begin{tabular}{|c|c|c|c|}
\hline & $\begin{array}{c}\text { Group I } \\
\text { Mean士SD }\end{array}$ & $\begin{array}{c}\text { Group } 2 \\
\text { Mean士SD }\end{array}$ & $\mathbf{p}$ \\
\hline Mean keratometry (D) & $43.6 \pm 1.95$ & $42.99 \pm 1.60$ & 0.08 \\
\hline Mean topographic cylinder (D) & $-3.77 \pm 2.81$ & $-5.03 \pm 5.59$ & 0.1 \\
\hline UCVA (decimal) & $0.52 \pm 0.27$ & $0.66 \pm 0.31$ & 0.07 \\
\hline DCVA (decimal) & $0.68 \pm 0.28$ & $0.77 \pm 0.26$ & 0.07 \\
\hline SE (D) & $0.86 \pm 1.87$ & $0.86 \pm 1.28$ & 0.97 \\
\hline Mean manifest cylinder (D) & $-2.8 I \pm 2.56$ & $-2.23 \pm-2.21$ & 0.16 \\
\hline
\end{tabular}

D: diopters; DCVA: distance corrected visual acuity; SE: spherical equivalent; UCVA: uncorrected distance visual acuity. 
Table 3. Postoperative clinical findings

\begin{tabular}{|c|c|c|c|}
\hline & $\begin{array}{c}\text { Group I } \\
\text { Mean士SD }\end{array}$ & $\begin{array}{c}\text { Group } 2 \\
\text { Mean士SD }\end{array}$ & $\mathbf{p}$ \\
\hline Mean keratometry (D) & $44.4 \pm 1.7$ & $44.1 \pm 1.3$ & $>0.05$ \\
\hline Mean topographic cylinder (D) & $-1.5 \pm 1.6$ & $-0.84 \pm 0.7$ & $>0.05$ \\
\hline UCVA (decimal) & $0.76 \pm 0.2$ & $0.84 \pm 0.3$ & $>0.05$ \\
\hline DCVA (decimal) & $0.90 \pm 0.02$ & $0.92 \pm 0.07$ & $>0.05$ \\
\hline SE (D) & $0.04 \pm 0.02$ & $0.1 I \pm 0.04$ & $>0.05$ \\
\hline Mean manifest cylinder (D) & $-1.03 \pm 0.3$ & $0.66 \pm 0.2$ & $>0.05$ \\
\hline
\end{tabular}

D: diopters; DCVA: distance corrected visual acuity; SE: spherical equivalent; UCVA: uncorrected distance visual acuity.

Table 4. Complications

\begin{tabular}{lccccc} 
& \multicolumn{2}{c}{$\begin{array}{c}\text { Primary } \\
\text { pterygium }\end{array}$} & & \multicolumn{2}{c}{$\begin{array}{c}\text { Recurrent } \\
\text { pterygium }\end{array}$} \\
\cline { 2 - 3 } \cline { 5 - 6 } & Fibrin Glue & Suture & & Fibrin Glue & Suture \\
\hline Hematoma & $\mathrm{I}$ & $\mathrm{I}$ & & 0 & $\mathrm{I}$ \\
Dellen & $\mathrm{I}$ & 0 & & 0 & $\mathrm{I}$ \\
Tenon's granuloma & $\mathrm{I}$ & $\mathrm{I}$ & & 0 & 2 \\
Folding of graft & $\mathrm{I}$ & 0 & & $\mathrm{I}$ & 0 \\
Conjunctival cyst & $\mathrm{I}$ & 2 & & $\mathrm{I}$ & 0 \\
\hline
\end{tabular}

\section{Discussion}

In this study, we evaluated the results of pterygium surgery with a conjunctival limbal autograft in cases of primary and recurrent pterygium. We found a statistically significant relationship between preoperative corneal astigmatism and preoperative pterygium length. Other studies in the literature have reported similar findings $(17,18)$. After the surgery, visual acuity and corneal topographical findings improved as expected, and no sight-threatening complications were seen in this study in either group.

The most important problem after pterygium surgery is recurrence. Accordingly, multiple strategies and new techniques have been developed to reduce the high rate of pterygium recurrence. In this study, the recurrence rate in Group I and Group 2 was $0 \%$ and I.75\%, respectively. It is well established in the literature that recurrence is more frequent in younger patients (19). In this study, the only patient to experience recurrence was younger than 40 years of age. Various studies in the literature have evaluated recurrence rates after pterygium surgery with a conjunctival limbal autograft (12-15). Consistent with our study results, several other authors have reported lower recurrence rates in cases of primary pterygium $(12,13)$. However, the recurrence rate after surgery in primary and recurrent pterygium cases seen in the literature varies $(12-15,13)$. These differences are probably related to surgical technique and the definition of recurrence. As in our study, Kenyon et al. (12) reported that none of the patients with primary pterygium experienced recurrence, while Allan et al. (20) reported a recurrence rate of $6.5 \%$. Although there was a lower rate of recurrence in the primary pterygium group in our study, the small number of recurrences (only I) prevents us from drawing a statistically significant conclusion. The low recurrence rate in this study is probably related to a wide excision of pterygium tissue with the surrounding conjunctiva, a large conjunctival graft with limbal tissue, and the surgeon's experience. Furthermore, we may have found a higher rate of recurrence with a longer follow-up period.

The most important limitation of this study is the relatively short length of follow-up and the retrospective design. However, the large number of cases performed by a single surgeon is a major strength.

In conclusion, we evaluated the surgical results of pterygium surgery and found that excision with a conjunctival limbal autograft is a safe and effective method for the surgical treatment of pterygium in primary and recurrent cases. The recurrence rate was very low, whether the graft was fixed in place using interrupted nylon sutures or FG.

\section{Disclosures}

Peer-review: Externally peer-reviewed.

Conflict of Interest: None declared.

\section{References}

I. Hirst LW. Recurrent pterygium surgery using pterygium extended removal followed by extended conjunctival transplant: recurrence rate and cosmesis. Ophthalmology 2009; I 16:127886. [CrossRef]

2. Shiroma H, Higa A, Sawaguchi S, Iwase A, Tomidokoro A, Amano $S$, et al. Prevalence and risk factors of pterygium in a southwestern island of Japan: the Kumejima Study. Am J Ophthalmol 2009; I 48:766-7I.el. [CrossRef]

3. Srinivasan S, Dollin M, McAllum P, Berger Y, Rootman DS, Slomovic AR. Fibrin glue versus sutures for attaching the conjunctival autograft in pterygium surgery: a prospective observer masked clinical trial. Br J Ophthalmol 2009;93:2/5-8. [CrossRef]

4. Xu Y, Zhou HM, Li J, Ke BL, Xu X. Efficacy of treatment for pterygium by autologous conjunctival transplantation and mitomycin C. Chin Med J (Engl) 20I2; I25:3730-4.

5. Huerva V, March A, Martinez-Alonso M, Muniesa MJ, Sanchez C. Pterygium surgery by means of conjunctival autograft: long term follow-up. Arq Bras Oftalmol 2012;75:25I-5. [CrossRef]

6. Kucukerdonmez C, Karalezli A, Akova YA, Borazan M. Amniotic membrane transplantation using fibrin glue in pterygium surgery: a comparative randomised clinical trial. Eye (Lond) 
2010;24:558-66. [CrossRef]

7. Chui J, Coroneo MT, Tat LT, Crouch R, Wakefield D, Di Girolamo N. Ophthalmic pterygium: a stem cell disorder with premalignant features. Am J Pathol 20I I; I78:8I7-27. [CrossRef]

8. Sekundo W, Droutsas K, Cursiefen C. Operative techniques for surgical treatment of primary and recurrent pterygia. [Article in German]. Ophthalmologe 2010;107:525-8. [CrossRef]

9. Jiang J, Gong J, Li W, Hong C. Comparison of intra-operative $0.02 \%$ mitomycin $C$ and sutureless limbal conjunctival autograft fixation in pterygium surgery: five-year follow-up. Acta Ophthalmol 2015;93:e568-72. [CrossRef]

10. Kurian A, Reghunadhan I, Nair KG. Autologous blood versus fibrin glue for conjunctival autograft adherence in sutureless pterygium surgery: a randomised controlled trial. $\mathrm{Br} J$ Ophthalmol 2015;99:464-70. [CrossRef]

I I. Taylan Sekeroglu H, Erdem E, Dogan NC, Yagmur M, Ersoz R, Dogan A. Sutureless amniotic membrane transplantation combined with narrow-strip conjunctival autograft for pterygium. Int Ophthalmol 201 1;31:433-8. [CrossRef]

12. Kenyon KR, Wagoner MD, Hettinger ME. Conjunctival autograft transplantation for advanced and recurrent pterygium. Ophthalmology 1985;92: I46 I-70. [CrossRef]

13. Prabhasawat P, Barton K, Burkett G, Tseng SC. Comparison of conjunctival autografts, amniotic membrane grafts, and primary closure for pterygium excision. Ophthalmology 1997; 104:974-
85. [CrossRef]

14. Sanchez-Thorin JC, Rocha G, Yelin JB. Meta-analysis on the recurrence rates after bare sclera resection with and without mitomycin $\mathrm{C}$ use and conjunctival autograft placement in surgery for primary pterygium. Br J Ophthalmol 1998;82:66I-5.

15. Young AL, Leung GY, Wong AK, Cheng LL, Lam DS. A randomised trial comparing $0.02 \%$ mitomycin $C$ and limbal conjunctival autograft after excision of primary pterygium. $\mathrm{Br} J$ Ophthalmol 2004;88:995-7. [CrossRef]

16. Al Fayez MF. Limbal versus conjunctival autograft transplantation for advanced and recurrent pterygium. Ophthalmology 2002; 109:1752-5. [CrossRef]

17. Ermiş SS, İnan Ü, Öztürk F. Analysis of the correlation between pterygium size and induced astigmatism [Article in Turkish]. T Klin J Ophthalmol 200I;10:171-4.

18. Oner FH, Kaderli B, Durak I, Cingil G. Analysis of the pterygium size inducing marked refractive astigmatism. Eur J Ophthalmol 2000;10:212-4. [CrossRef]

19. Güler M, Sobaci G, Ilker S, Oztürk F, Mutlu FM, Yildirim E. Limbal conjunctival autogreft transplantation in cases with recurrent pterygium. Acta Ophthalmol 1994;72:721-6. [CrossRef]

20. Allan BD, Short P, Crawford GJ, Barrett GD, Constable IJ. Pterygium excision with conjunctival autografting: an effective and safe technique. Br J Ophthalmol 1993;77:698-70I. [CrossRef] 